\title{
Carcinogenic Nitrosourea
}

National Cancer Institute

\section{Source}

National Cancer Institute. Carcinogenic Nitrosourea. NCI Thesaurus. Code C45411.

Any of several chemically related nitrosourea-derivates that increases the risk of human cancer and are highly lipid-soluble and act by alkylation, carbamoylation, and inhibition of DNA repair. $(\mathrm{NCl05})$ 